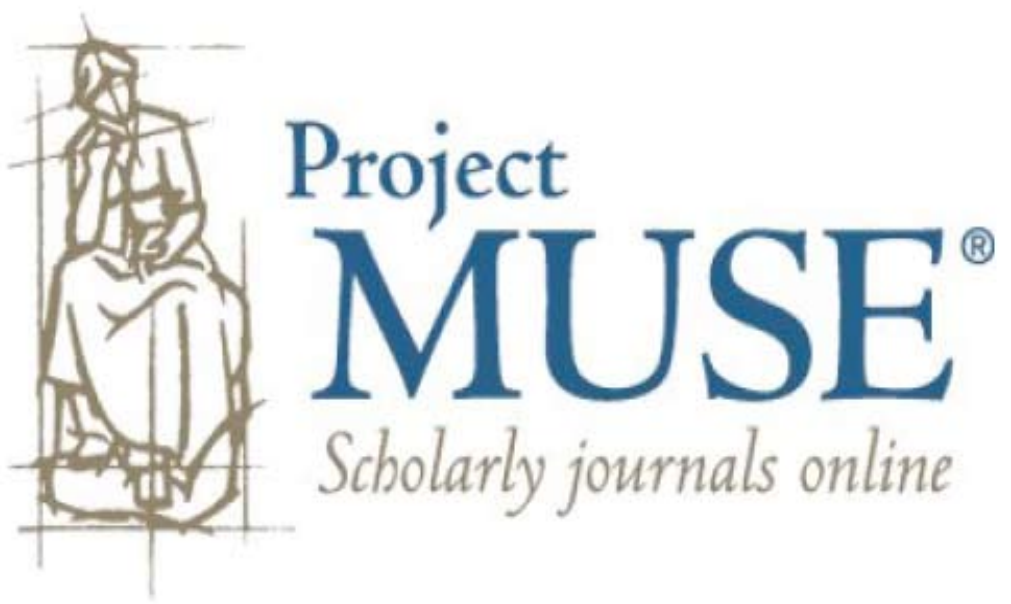




\section{Women Students at Coeducational and Women's Colleges: How Do Their Experiences Compare?}

Jillian Kinzie

Paul D. Umbach

\author{
Auden D. Thomas \\ George D. Kuh
}

\author{
Megan M. Palmer
}

This study compared the experiences of women attending women's colleges with those of women attending coeducational institutions. Analyses of data from the National Survey of Student Engagement (NSSE) from random samples of female first-year and senior students from 26 women's colleges and 264 other four-year institutions were conducted. Women at single-sex institutions were more engaged in effective educational practices and reported higher levels offeelings of support and greater gains in college. With regard to the effect of different backgrounds on college experiences, transfer students at women's colleges were as engaged or more engaged than students who start at and graduate from the same school, and students of color tended to be less engaged than White students.

Are women's colleges as rich with educational opportunity for their students as their proponents claim? Or, is the quality of women's educational experience across institutional types equivalent now that women outnumber and typically outperform men on coeducational campuses? Few question the valuable role that women's colleges played in the history of American higher education. From its beginnings as an enterprise established by men for men, to early experiments in coeducation marked by isolating women and limiting their participation in university life (Miller-Bernal,
2000; Nidiffer, 2001; Solomon, 1985), women were an afterthought. Given this historical legacy, it is remarkable that today women outnumber and in many respects perform better than their male counterparts. In fact, they have comprised the majority of undergraduates for more than 2 decades (National Center for Education Statistics, 2006). Moreover, women are more likely than their male peers to hold high educational aspirations, to enroll in college, and to persist to degree attainment (Bae, Choy, Geddes, Sable, \& Snyder, 2000). Though impressive, women's gains in numerical representation and achievement may mask more complex issues of gender inequity in the academy.

Despite the advances made by women in higher education, women still face gendered norms and expectations that constrain their choice of field of study and occupation and consequently perpetuate tangible inequities including lower wages, underemployment, and segregated occupations (see Nelson \& Rogers, 2004; U.S. Department of Labor, 2003). Since 1982, when Hall and Sandler reported a chilly campus climate for female undergraduates, the quality of the learning environment for women at coeducational colleges and universities has been a topic of justified concern. Though evidence supporting the chilly campus climate thesis is somewhat limited, what does exist

Jillian Kinzie is Associate Director of the Center for Postsecondary Research at Indiana University Bloomington. Auden D. Thomas is Director of the Center for Survey Research at Pennsylvania State University-Harrisburg. Megan M. Palmer is Executive Director of the Center for Teaching and Learning at Indiana University Purdue University Indianapolis. Paul D. Umbach is Assistant Professor of Higher Education at University of Iowa. George D. Kuh is Chancellor's Professor and Director of the Center for Postsecondary Research at Indiana University Bloomington. 
suggests that compared with men, many women perceive their campus to be less supportive of their academic and social needs and that, as a result, their learning and personal development is adversely affected (Drew \& Work, 1998; Pascarella et al., 1997; Rice, 1991). For example, Pascarella and his colleagues found a handful of moderately sized negative relationships between perceptions of chilly campus climate and selected intellectual and personal development outcomes (Pascarella et al., 1997). This pattern persisted through the junior year, wherein students who perceived their campus climate to be "chilly" had lower gains in writing and thinking skills, science knowledge, and arts and humanities knowledge (Whitt, Edison, Pascarella, Nora, \& Terenzini, 1999).

Female students have been and continue to be underrepresented in positions of leadership on coeducational campuses (Astin, 1993). In part, this may be because women students have qualitatively different leadership styles and experiences during college (Astin, 1993; Kezar \& Moriarty, 2000; Whitt, 1994). In addition, women who might serve as role models are underrepresented in senior administrative and faculty positions (Nidiffer \& Bashaw, 2001). As these and other microinequities accrue over time, they have "a damaging cumulative effect, creating an environment that dampens women's selfesteem, confidence, aspirations and their participation" (Sandler, n.d. I 1). Such inequities are especially marked in areas where women are underrepresented, such as science, mathematics, and technology (Davis et al., 1996; Nelson \& Rogers, 2004; Knapp, Kelly, Whitmore, Wu, Gallego, \& Grau, E, 2001). In these instances, the paltry proportions of women students in classes contribute to women's feelings of lack of belonging as learners and to discomfort in the learning environment. This is particularly true for re- entry women (Hayes \& Flannery, 2000) and women of color (Wolf-Wendel, 1998) who are more likely to feel like outsiders because, on the majority of college campuses, their numbers remain relatively small. With coeducational colleges and universities enrolling $98 \%$ of all female students, the learning climate for women collegians on these campuses warrants continuous monitoring, especially compared with women's colleges, which a considerable body of research suggests provide numerous educational and personal development advantages for their students.

Indeed, single-sex educational environments have been hailed as "models of what institutions dedicated to women can mean" (Smith, 1989, p. 50). With a long history of providing women access to higher education, the nation's 68 women's colleges trumpet "taking women's education seriously" as a core institutional value. Advocates of women's colleges point to research studies that show these institutions provide a qualitatively superior learning environment for their students (Astin, 1993; Riordan, 1994; Sharp, 1991; Tidball, Smith, Tidball, \& Wolf-Wendel, 1999; Whitt, 1994). For example, women attending women's colleges are 1.5 times more likely to earn baccalaureate degrees in the life and physical sciences or math than women at coeducational institutions (Sebrechts, 1992; Sharpe \& Fuller, 1995). Compared with their counterparts at coeducational colleges and universities, women attending women's colleges exhibit greater gains in such cognitive areas as academic and intellectual development (Astin, 1993; Baxter Magolda, 1992); academic involvement (National Survey of Student Engagement [NSSE], 2003; Smith, 1990; Smith, Wolf, \& Morrison, 1995); intellectual self-confidence (Kim, 2002); and self-perceived academic ability (Kim \& Alvarez, 1995). The less paternalistic culture and rituals characteristic of women's colleges provide students more 
support to assume leadership, reward collective achievements, and move beyond traditional gender roles (Manning, 1994, 2000). Women at women's colleges also evidence gains in noncognitive outcomes in such areas as selfesteem and confidence (Astin, 1977; Holland \& Eisenhart, 1990; Smith et al., 1995) and leadership development (Astin, 1993; Astin \& Leland, 1991; Whitt, 1994). Finally, students at women's colleges are more satisfied overall with their college experience (Langdon, 2001; NSSE, 2003; Smith, 1990) and with their interactions with faculty (Astin, 1977, 1993; Smith, 1990). The lone exception to this litany of positive outcomes is that students at women's colleges tend to be less satisfied with the quality of social life their campuses afford (Astin, 1993; Smith, 1990; Smith et al., 1995).

Tidball's (1973, 1980, 1985, 1986) extensive body of widely cited baccalaureate origin research suggests a positive relationship between attendance at a women's college and alumnae career attainment. Women's college alumnae were more likely to be women "achievers," defined as those recognized in Who's Who in America. Tidball also found a positive relationship between women achievers and the percentage of women on the faculty. Tidball, and more current research by others (Riordan, 1994; Tidball et al., 1999; WolfWendel, 1998), found that women's colleges produced more graduates who attained doctorates in nontraditional fields than did coeducational colleges. Women graduating from women's colleges were more likely than women graduating from coeducational institutions to attain the doctorate in a wider range of major fields, such as science, arts, humanities, and social sciences, whereas coeducational women graduates were likely to earn a doctorate in fewer fields, and were particularly well represented in traditionally female fields including education.
Although Tidball's research faced challenges (Crosby et. al., 1994; Giele, 1987; Stoecker \& Pascarella, 1991) on the basis that it did not control for student and institutional background characteristics, subsequent studies (Astin, 1993; Riordan, 1992; Smith et al., 1995; Wolf-Wendel, 1998; Wolf-Wendel, Baker, \& Morphew, 2000) that controlled for respondents' socioeconomic backgrounds and/or institutional selectivity confirmed Tidball's original assertions that women's colleges contribute to the disproportionate success of their students. Assuming that women attending single-sex colleges enjoy educational and personal development advantages, there remains a good deal to learn about the policies and practices that make these institutions distinctively powerful learning environments for their students.

Riordan (1994) observed that the impact of single-sex education is still "an unresolved empirical question” (p. 487). After reviewing the literature, Harwarth (1999) concluded there was a lack of diversity in the quantitative data available to fairly judge the efficacy of women's colleges and called for additional studies that used new databases. For example, many of the more prominent studies of the experiences of women at women's colleges, such as those by Astin (1977, 1993), Smith (1990), Smith, Morrison \& Wolf (1994), Smith et al. (1995), and Kim \& Alvarez (1995), rely on the same data sources, UCLA's Cooperative Institutional Research Program Freshman Survey and College Student Survey. Although these studies have contributed greatly to our understanding of women's colleges, it supports Harwarth's (1999) assertion that scholars are "examining the same database over and over and reaching the same conclusions" (p. 14). Perhaps a new database will add to the richness of previous research by providing additional information about the unique educational experiences women have 
at women's colleges. In addition, because women are not a monolithic group and their experiences differ (Hurtado, Carter, \& Kardia, 1998; Sandler, Silverberg, \& Hall, 1996), more research is needed on the impact of college environments on student learning outcomes for all women (Whitt et al., 1999).

\section{Purpose of the Study}

In this study we compared the experiences of women attending women's colleges with those of women attending coeducational institutions. Two research questions guided the inquiry:

1. Do women's colleges differ from coeducational institutions in terms of students' satisfaction with their experiences, the nature and frequency of interactions with peers and faculty members, and participation in a variety of educationally purposeful activities associated with desired college outcomes?

2. Do students at women's colleges from different backgrounds (e.g., transfers, women of color) differ in terms of their college experiences?

\section{METHODS}

To determine the ways that women's colleges differ from comparable coeducational institutions in terms of students' satisfaction with their experiences, interaction with peers and faculty members, educational gains, and participation in a variety of activities associated with desired college outcomes, data from the NSSE were used. The NSSE measures these aspects of the undergraduate experience on an annual basis, collecting data from randomly selected first-year and senior students at hundreds of U.S. four-year colleges and universities. Institutions choosing to participate in NSSE closely resemble the national profile of four-year colleges and universities in terms of region of the country and location, and Carnegie classification (with slightly more Doctoral/Research Universities and Baccalaureate Colleges-Liberal Arts as defined by the 2000 Carnegie Classification of Institutions of Higher Education). The average response rate for both paper and Web-based survey administrations is about $41 \%$.

The NSSE data set was selected for two reasons. First, NSSE is one of the most comprehensive surveys of the student experience to date. Given that we designed our research questions to offer an in-depth examination of women's educational experiences in college, NSSE provides an excellent data source. Second, the NSSE data set has an unusually large number of women's institutions represented. Twenty-six of the 68 women's institutions are included in the 2000, 2001, and 2002 NSSE data set. Few, if any researchers have included as many women's colleges as we have in this study.

Research on the college student experience suggests that students learn more when they are engaged at reasonably high levels in a variety of educationally purposeful activities (Astin, 1984; Kuh, Douglas, Lund, \& RaminGyurnek, 1994; Kuh, Schuh, Whitt \& Associates, 1991; Pascarella \& Terenzini, 1991, 2005; Tinto, 1987). Student engagement, which NSSE measures, represents two critical features. The first is the amount of time and effort students put into their studies and other educationally purposeful activities traditionally associated with learning, such as reading and writing, preparing for class, collaborating with peers on projects, problem-solving tasks, community service, and interacting with instructors about various matters (Kuh, 2001). The second is how the institution deploys its resources and organizes the curriculum, other learning opportunities, and support services to induce students to participate in activities that lead to the experiences and desired 
outcomes (persistence, satisfaction, learning, and graduation). Research shows that engagement in educationally purposeful activities contributes to high levels of learning and personal development (Pascarella \& Terenzini, $1991,2005)$. Indeed, participating in educationally purposeful activities directly influences the quality of students' learning and their overall educational experience.

NSSE was specifically designed to assess the extent to which students are engaged in empirically derived good educational practices and what they gain from their college experience (Kuh, 2001). The good educational practices that NSSE measures were derived from Chickering and Gamson's (1987) principles for good practice in undergraduate education. A significant body of evidence exists to support the predictive validity of these principles (Astin, 1993; Kuh et al., 1991; Pascarella \& Terenzini, 1991, 2005). Although NSSE doesn't assess student learning outcomes directly, the main content of the NSSE instrument, The College Student Report, represents student behaviors that are highly correlated with many desirable learning and personal development outcomes of college.

The sample for this study consisted of 42,112 female first-year and senior students who completed the NSSE in Spring, 2000, 2001 , or 2002. By combining three years of data we have a robust sample from women's colleges. Two hundred ninety different fouryear colleges and universities were represented, including 4,676 women at 26 women's colleges and the remainder at 264 other institutions from the same Carnegie categories as the women's colleges (private Master's I and II Universities, Liberal Arts Colleges, and Baccalaureate General Colleges). Women's colleges looked only slightly different than the coeducational institutions. In terms of Carnegie Classification, approximately $46 \%$ of the women's colleges were classified as Baccalau-
reate-Liberal Arts, whereas only 32\% of the coeducational colleges were classified as Baccalaureate-Liberal Arts. Master's institutions were over-represented among coeducational colleges (45\% compared to $35 \%$ for women's colleges). According to Barron's Profiles of American Colleges (2003), 42\% of the coeducational colleges and $31 \%$ of the women's colleges were considered very competitive, highly competitive, or most competitive in terms of selectivity. It is important to use similar coeducational examples for comparison purposes. Neither of the two existing historically Black colleges serving women in the U.S. is included in this study and only one of the remaining five "Seven Sister" colleges are represented among the women's colleges.

\section{Data Analysis}

The data were analyzed in two stages. First, we built models to examine the engagement of first-year and senior women at coeducational institutions and at women's colleges. We elected to conduct separate analyses for firstyear and senior students because students' experiences on the kinds of activities NSSE measures, such as the extent to which they interact with faculty to discuss career plans, or degree to which they experience coursework emphasizing higher order thinking, usually differ between first-year students-students who are relatively new to the college or university - as compared to seniors (Kuh, 2003a, 2005). For example, seniors typically report greater overall gains than first-year students (Kuh, 2003a; NSSE, 2003, 2004). Differences in the engagement levels of seniors and first-year students emphasize the importance of running separate models. Because of the nested nature of the data and the intent to estimate institutional effects (Raudenbush \& Bryk, 2002), we used hierarchical linear modeling (HLM). Underlying our analysis was the assumption that institutions have a 
differential impact on the student experience. In other words, students were nested within institutions. Given this notion of nesting, we can no longer assert that our observations are independent from one another, which is a fundamental assumption in ordinary least squares (OLS) regression, because two students from one institution are more likely to have similar collegiate experiences compared with two students from different institutions. To overcome the problems faced with nested data, we employed HLM.

Using HLM also has several advantages over OLS regression. First, HLM allows for the partitioning of variance between the institution and the student, allowing for more accurate estimates. In other words, HLM allows for us to determine what variance can be attributed to the individual and what variance can be attributed to the institution. We can then model these simultaneously. In OLS, the variance cannot be accurately partitioned, thereby making it difficult to attribute what is an individual level effect or a group level effect. By allowing the intercept to vary in HLM, we were able to partition the variance and model institutional averages using group-level characteristics.

Second, the inclusion of group-level variables into an OLS regression equation resulted in the misestimation of standard errors and the wrong number of degrees of freedom. For example, if we included a women's college variable, our degrees of freedom would be based incorrectly on 42,112 respondents, when in fact it should be based on 290 institutions in our data. In our example, the probability of making a Type I error (i.e., finding significance when actually the findings were insignificant) is much greater if we were to use OLS to estimate the women's college effect. Finally, because HLM takes into account the within school sample size through weighting, it was unnecessary to equalize the sample size across schools.
To aid in interpretation of coefficients, all of the findings of our HLM analyses are displayed as effect sizes. Effect sizes are useful when assessing the magnitude of the relationship between a dependent and independent variable. An effect size is the proportion of a standard deviation change in the dependent variable as a result of a one-unit change in an independent variable. When we standardize all of the continuous measures (both independent and dependent) in our models, the unstandardized coefficients represent effect sizes. An effect size of .10 or less is considered trivial, between .10 and .30 is small, between .30 and .50 is moderate, and greater than .50 is large (Rosenthal \& Rosnow, 1991).

We conducted our modeling in two stages. First, we built separate models for first-year and senior students using the 42,112 at 290 institutions. Because we were interested in understanding the average effect of attending a women's college, we allowed the intercept to vary and included a dummy-coded variable at Level 2 (the institution level) that represented women's colleges. We also included controls at both the institution and student level. These controls represent known influences on the impact of college (Pascarella \& Terenzini, 2005). At the student level, we controlled for race and ethnicity, age, enrollment status, transfer status, and major field. At the institution level we controlled for institution type, urban location, selectivity (derived from Barron's Profiles of American Colleges, 2003), size, and proportion of full-time students. Thus, the coefficient for the women's college variable represents the average difference between women's colleges and coeducational colleges controlling for both individual and institution level characteristics. Detailed operational definitions of these variables are available on request from the fifth author.

Second, we built hierarchical linear models using only students from the 26 women's 
colleges to explore individual differences in engagement within those institutions. With only 26 institutions in this analysis we could not use group level measures. However, we allowed the intercept to vary, thereby partitioning the variance that could be attributed to the institution. Again, we constructed models for both first-year and senior students.

Multiple dependent measures of student engagement were used. Table 1 displays the factor loadings and alpha reliabilities for the dependent measures, ranging from .59 to .80 . We created nine scales, including three subscales, to represent engagement. Academic challenge is composed of 10 items that measure reading, writing, and time spent preparing for class. Higher order thinking is a subscale of academic challenge made up of four measures based on Bloom's taxonomy (time spent synthesizing ideas, making judgments, applying theories, and analyzing ideas) that describe the nature of the cognitive activities emphasized in classes. Integration measures the degree to which institutions emphasize activities that foreshadow deep learning (e.g., discussions of ideas from readings or classes with faculty members or others outside of class, working on a paper or project that required integrating ideas or information from various sources). The active and collaborative learning measure has seven items (e.g., working with other students in and out of class, asking questions in class, making a class presentation). Studentfaculty interaction is a five-item scale covering a range of contacts inside and outside the classroom. Experiences with diversity is a three-item scale that measures student interactions with people of different backgrounds and the emphasis a campus places on encouraging these interactions.

We also created scales from NSSE items to measure students' perceptions of the degree to which their school provided support for their academic and social development.
Supportive campus climate is a six-item construct that measures student perceptions of institutional support and the quality of relationships among students, faculty members, and administrators. Two supportive campus climate subscales were created, interpersonal support, and support for success. Interpersonal support is a three-item measure of the quality of student relationships with faculty, staff, and other students. Support for success is a threeitem scale that represents students' beliefs about campus support for academic and nonacademic success. Satisfaction is measured with two items.

We included student self-reported gains in our analyses, because many claims about the superiority of women's colleges are related to the degree to which students benefit intellectually and socially from the experience. One self-reported gains measure is a four-item scale that focuses on general education outcomes (e.g., general education, writing, speaking, and critical thinking). A four-item scale represents student gains in understanding self and others. Of the two single-item gains measures, one represents quantitative skills and the other, one's willingness to contribute to the welfare of the community. The former is of interest because of the literature that suggests that women at women's colleges are more likely to excel and pursue graduate study in mathematics and science than women who attend coeducational colleges. The latter reflects the emphasis that women's colleges give to community service as an educational value in the curriculum.

Before running our models, we estimated the proportion of variance explained by college membership (between-college variance) and individuals (within-school variance) by running the null model. Table 2 shows these estimates. The proportion of variance between institutions is somewhat small, ranging from .02 to .12 . Given these nontrivial proportions and 
TABLE 1.

Dependent Variables, Factor Loadings, and Alpha Coefficients

\begin{tabular}{cc}
\hline \multirow{2}{*}{ Factor Loadings } \\
\cline { 2 - 3 }
\end{tabular}

\section{Student Engagement Scales and Items ${ }^{a}$}

Academic Challenge

$(\alpha=.73) \quad(\alpha=.72)$

Worked harder than you thought you could to meet an instructor's standards or expectations $\quad \begin{array}{lll}0.50 & 0.53\end{array}$

Preparing for class

$0.40 \quad 0.43$

Number of assigned textbooks, books, or book-length packs of course readings

0.40

0.36

Number of written papers or reports of 20 pages or more

$0.36 \quad 0.34$

Number of written papers or reports of 19 pages or less

$0.38 \quad 0.33$

Emphasize: Spending significant amounts of time studying and on academic work

$0.45 \quad 0.48$

Coursework emphasizes: Analyzing the basic elements of an idea, experience, or theory

0.71

0.73

Coursework emphasizes: Synthesizing and organizing ideas, information, or experiences

0.76

0.77

Coursework emphasizes: Making judgments about the value of information,

arguments, or methods

0.70

Coursework emphasizes: Applying theories or concepts to practical problems or

in new situations

0.67

Higher Order Thinking

Coursework emphasizes: Synthesizing and organizing ideas, information, or experiences

Coursework emphasizes: Making judgments about the value of information, arguments, or methods

Coursework emphasizes: Applying theories or concepts to practical problems or in new situations

Coursework emphasizes: Analyzing the basic elements of an idea, experience, or theory

$(\alpha=.79) \quad(\alpha=.80)$

$0.82 \quad 0.82$

$0.79 \quad 0.78$

$0.75 \quad 0.77$

$0.77 \quad 0.78$

Integration

Worked on a paper or project that required integrating ideas or information

from various sources

Put together ideas or concepts from different courses when completing assignments or during class discussions

Discussed ideas from your readings or classes with faculty members outside of class

Discussed ideas from your readings or classes with others outside of class

(students, family members, coworkers, etc.)

$(\alpha=.69) \quad(\alpha=.71)$

$0.65 \quad 0.65$

$0.69 \quad 0.69$

$0.68 \quad 0.68$

Active and Collaborative Learning

Asked questions in class or contributed to class discussions

Made a class presentation

$(\alpha=.61) \quad(\alpha=.59)$

$0.50 \quad 0.56$

$0.68 \quad 0.58$

$\begin{array}{lll}\text { Participated in a community-based project as part of a regular course } & 0.52 & 0.44\end{array}$

Worked with other students on projects during class

$0.54 \quad 0.47$

Worked with classmates outside of class to prepare class assignments

$0.65 \quad 0.62$

Tutored or taught other students

$0.45 \quad 0.55$

Discussed ideas from your readings or classes with others outside of class

$0.46 \quad 0.53$

Student-Faculty Interaction

Discussed grades or assignments with an instructor

$(\alpha=.76) \quad(\alpha=.73)$

$0.72 \quad 0.72$

Talked about career plans with a faculty member or advisor

0.79

0.74

Discussed ideas from your readings or classes with faculty members outside of class

0.79

0.76

Received prompt feedback from faculty on your academic performance

0.63

0.62

Worked with faculty members on activities other than coursework

0.65

0.61

table continues 
TABLE 1. continued

Dependent Variables, Factor Loadings, and Alpha Coefficients

\begin{tabular}{|c|c|c|}
\hline & \multicolumn{2}{|c|}{ Factor Loadings } \\
\hline & 1st Year & Senior \\
\hline Diversity Experiences & $(\alpha=.64)$ & $(\alpha=.63)$ \\
\hline \multirow{3}{*}{$\begin{array}{l}\text { Had serious conversations with students of a different race or ethnicity than your own } \\
\text { Contributed to: Understanding people of other racial and ethnic backgrounds } \\
\text { Emphasize: Encouraging contact among students from different economic, social, } \\
\text { and racial/ethnic backgrounds }\end{array}$} & 0.67 & 0.66 \\
\hline & 0.82 & 0.82 \\
\hline & 0.79 & 0.79 \\
\hline \multicolumn{3}{|l|}{ Supportive Campus Climate ${ }^{b}$} \\
\hline Supportive Campus Environment & $(\alpha=.78)$ & $(\alpha=.79)$ \\
\hline \multirow{5}{*}{$\begin{array}{l}\text { Emphasize: Providing the support you need to help you succeed academically } \\
\text { Emphasize: Helping you cope with your nonacademic responsibilities } \\
\text { Emphasize: Providing the support you need to thrive socially } \\
\text { Quality: Your relationships with other students } \\
\text { Quality: Your relationships with faculty members } \\
\text { Quality: Your relationships with administrative personnel and offices }\end{array}$} & $\begin{array}{l}0.74 \\
0.75\end{array}$ & $\begin{array}{l}0.72 \\
0.74\end{array}$ \\
\hline & 0.76 & 0.76 \\
\hline & 0.53 & 0.58 \\
\hline & 0.71 & 0.72 \\
\hline & 0.65 & 0.69 \\
\hline Interpersonal Support & $(\alpha=.61)$ & $(\alpha=.67)$ \\
\hline \multirow{3}{*}{$\begin{array}{l}\text { Quality: Your relationships with other students } \\
\text { Quality: Your relationships with faculty members } \\
\text { Quality: Your relationships with administrative personnel and offices }\end{array}$} & 0.67 & 0.67 \\
\hline & 0.81 & 0.83 \\
\hline & 0.77 & 0.82 \\
\hline Support for Success & $(\alpha=.73)$ & $(\alpha=.76)$ \\
\hline \multirow{3}{*}{$\begin{array}{l}\text { Emphasize: Providing the support you need to help you succeed academically } \\
\text { Emphasize: Helping you cope with your nonacademic responsibilities } \\
\text { Emphasize: Providing the support you need to thrive socially }\end{array}$} & 0.75 & 0.74 \\
\hline & 0.87 & 0.87 \\
\hline & 0.85 & 0.86 \\
\hline Satisfaction & $(\alpha=.80)$ & $(\alpha=.79)$ \\
\hline \multirow{2}{*}{$\begin{array}{l}\text { How would you evaluate your entire educational experience at this institution? } \\
\text { If you could start over again, would you go to the same institution you are now attending? }\end{array}$} & 0.91 & 0.91 \\
\hline & 0.91 & 0.91 \\
\hline \multicolumn{3}{|l|}{ Self-Reported Gains } \\
\hline Understanding Self and Others & $(\alpha=.74)$ & $(\alpha=.75)$ \\
\hline Contributed to: Working effectively with others & 0.72 & 0.74 \\
\hline Contributed to: Learning effectively on your own & 0.77 & 0.74 \\
\hline Contributed to: Understanding yourself & 0.81 & 0.81 \\
\hline Contributed to: Understanding people of other racial and ethnic backgrounds & 0.71 & 0.73 \\
\hline General Education & $(\alpha=.77)$ & $(\alpha=.79)$ \\
\hline \multirow{4}{*}{$\begin{array}{l}\text { Contributed to: Acquiring a broad general education } \\
\text { Contributed to: Writing clearly and effectively } \\
\text { Contributed to: Speaking clearly and effectively } \\
\text { Contributed to: Thinking critically and analytically }\end{array}$} & 0.67 & 0.68 \\
\hline & 0.85 & 0.84 \\
\hline & 0.83 & 0.80 \\
\hline & 0.80 & 0.81 \\
\hline
\end{tabular}

Note. NSSE survey instrument is available: http://nsse.iub.edu/html/sample.cfm

a Response scale for most NSSE items is typically a 4-point scale ranging from 1 (never or very little) to 4 (very often or very much).

b Response scale for quality of relationship items is a 7-point scale ranging from 1 (unfriendly) to 7 (friendly, supportive). 
TABLE 2.

Results From HLM: Proportion of Variance Within and Between Institutions

\begin{tabular}{llllll}
\hline & \multicolumn{2}{c}{ 1st-Year Students } & & \multicolumn{2}{c}{ Senior Students } \\
\cline { 5 - 6 } Dependent Variable & Within & Between & & Within & Between \\
\hline Engagement & & & & & \\
$\quad$ Academic challenge & 0.94 & 0.06 & & 0.93 & 0.07 \\
$\quad$ Higher order thinking & 0.95 & 0.05 & & 0.96 & 0.04 \\
Active and collaborative learning & 0.95 & 0.05 & & 0.94 & 0.06 \\
$\quad$ Student-faculty interaction & 0.95 & 0.05 & & 0.93 & 0.07 \\
$\quad$ Integration & 0.93 & 0.07 & & 0.92 & 0.08 \\
$\quad$ Diversity-related activities & 0.88 & 0.12 & & 0.89 & 0.11 \\
Supportive Campus Climate & & & & & \\
$\quad$ Supportive campus environment & 0.97 & 0.03 & & 0.96 & 0.04 \\
$\quad$ Interpersonal support & 0.96 & 0.04 & & 0.95 & 0.05 \\
$\quad$ Support for success & 0.98 & 0.02 & & 0.97 & 0.03 \\
$\quad$ Satisfaction & 0.97 & 0.03 & & 0.97 & 0.03 \\
Self-Reported Gains & & & & \\
$\quad$ Understanding self and others & 0.92 & 0.08 & & 0.92 & 0.08 \\
$\quad$ General education & 0.95 & 0.06 & & 0.93 & 0.07 \\
$\quad$ Analyzing quantitative problems & 0.91 & 0.09 & & 0.92 & 0.08 \\
$\quad$ Contributing to welfare of community & 0.96 & 0.04 & & 0.96 & 0.04
\end{tabular}

that our research questions were focused on both college-level and individual-level effects, we proceeded with our analyses using HLM.

\section{RESULTS \\ Women's Colleges and Coeducational Colleges}

Table 3 shows the results of the hierarchical linear models comparing student engagement at women's and coeducational colleges. Note that developing practice within HLM methodology is to interpret significance at .10, because HLM tests of significance at the group level are conducted using the appropriate degrees of freedom $(N=290)$, and when there is prior evidence in the literature regarding the effect (Lee \& Byrk, 1989; Lee \& Smith, 1997; Mayer, 1998). In this study we interpret three levels of significance: $.10, .05$, and .01 . We mention four variables that are significant at the .10 level because they have been identified as having an effect in prior literature and have reasonable, though small, effect sizes in this study.

In general, women at single-sex colleges are more engaged than women at coeducational institutions. After controlling for both individual and institutional characteristics, both first-year and senior women attending women's colleges reported higher levels of academic challenge. Especially noteworthy is that seniors at women's colleges were more likely to engage in higher order thinking activities than seniors at coeducational institutions. Similarly, both seniors and first-year students at women's colleges scored higher on active and collaborative learning and studentfaculty interaction than their counterparts at coeducational institutions. Additionally, both 
first-year students and seniors at women's colleges were more likely to engage in integrative activities that lead to deep learning. The largest observed difference was related to experiences with diversity. Both first-year students and seniors at women's colleges reported that their campus environment encouraged and supported diverse interactions and an understanding of diversity to a greater degree than women at coeducational schools.

Nevertheless, students' perceptions of other aspects of the campus environment are somewhat mixed. For example, women attending the two categories of institutions did not differ in terms of their perceptions of the overall campus environment. However, seniors at women's colleges perceived a lower level of interpersonal support compared with their counterparts at coeducational schools, whereas first-year students at women's colleges perceived greater support for success. No differences were found in terms of student satisfaction.

In terms of gains, women's college respondents reported making more progress in every measure tested. Specifically, women's college students indicated greater gains in understanding themselves and others, general education, ability to analyze quantitative problems, and desire to contribute to the welfare of their community.

\section{Within Women's College Differences}

Engagement in Effective Educational Practices. Table 4 shows individual-level results from the within women's college models of student engagement. Some race- and ethnicity-related differences were found in engagement in effective educational practices. In the senior year, African American and Asian Pacific American (APA) students reported fewer interactions with faculty compared with White students. APA seniors were also less likely than White seniors to participate in active and collaborative learning activities and first-year
APA students scored lower on academic challenge. Both first-year and senior APA students indicated less involvement in integration activities than Whites.

We also observed differences related to major field for seniors. Except for active and collaborative learning, students at women's colleges majoring in the social sciences appear to be the most engaged, reporting the highest level of academic challenge, experiences with higher order mental activities, and diversity experiences. Students in professional programs scored high on the active and collaborative

TABLE 3.

Effect Sizes From HLM:

Comparing Women's Colleges to Coeducational Institutions

\begin{tabular}{|c|c|c|}
\hline Dependent Variable & $\begin{array}{l}\text { 1st-Year } \\
\text { Students }\end{array}$ & $\begin{array}{l}\text { Senior } \\
\text { Students }\end{array}$ \\
\hline \multicolumn{3}{|l|}{ Engagement } \\
\hline Academic challenge & $0.10^{\dagger}$ & $0.12 *$ \\
\hline Higher order thinking & 0.08 & $0.13 *$ \\
\hline $\begin{array}{l}\text { Active and collaborative } \\
\text { learning }\end{array}$ & $0.14 * *$ & $0.16 * *$ \\
\hline Student-faculty interaction & n $0.18 * *$ & $0.09^{\dagger}$ \\
\hline Integration & $0.16 * *$ & $0.17 * *$ \\
\hline Diversity-related activities & $0.31 * *$ & $0.27 * *$ \\
\hline \multicolumn{3}{|l|}{ Supportive Campus Climate } \\
\hline $\begin{array}{l}\text { Supportive campus } \\
\text { environment }\end{array}$ & 0.06 & -0.03 \\
\hline Interpersonal support & -0.02 & $-0.08 *$ \\
\hline Support for success & $0.11 *$ & 0.01 \\
\hline Satisfaction & 0.01 & 0.02 \\
\hline \multicolumn{3}{|l|}{ Self-reported Gains } \\
\hline $\begin{array}{l}\text { Understanding self and } \\
\text { others }\end{array}$ & $0.16 * *$ & $0.11 *$ \\
\hline General education & $0.11 *$ & $0.08^{\dagger}$ \\
\hline $\begin{array}{l}\text { Analyzing quantitative } \\
\text { problems }\end{array}$ & $0.09 *$ & $0.12 * *$ \\
\hline $\begin{array}{l}\text { Contributing to welfare } \\
\text { of community }\end{array}$ & $0.13 * *$ & $0.08^{\dagger}$ \\
\hline
\end{tabular}

${ }^{\dagger} p<.10 . \quad * p<.05 . \quad * * p<.01$. 
Kinzie, Thomas, Palmer, Umbach, \& Kuh

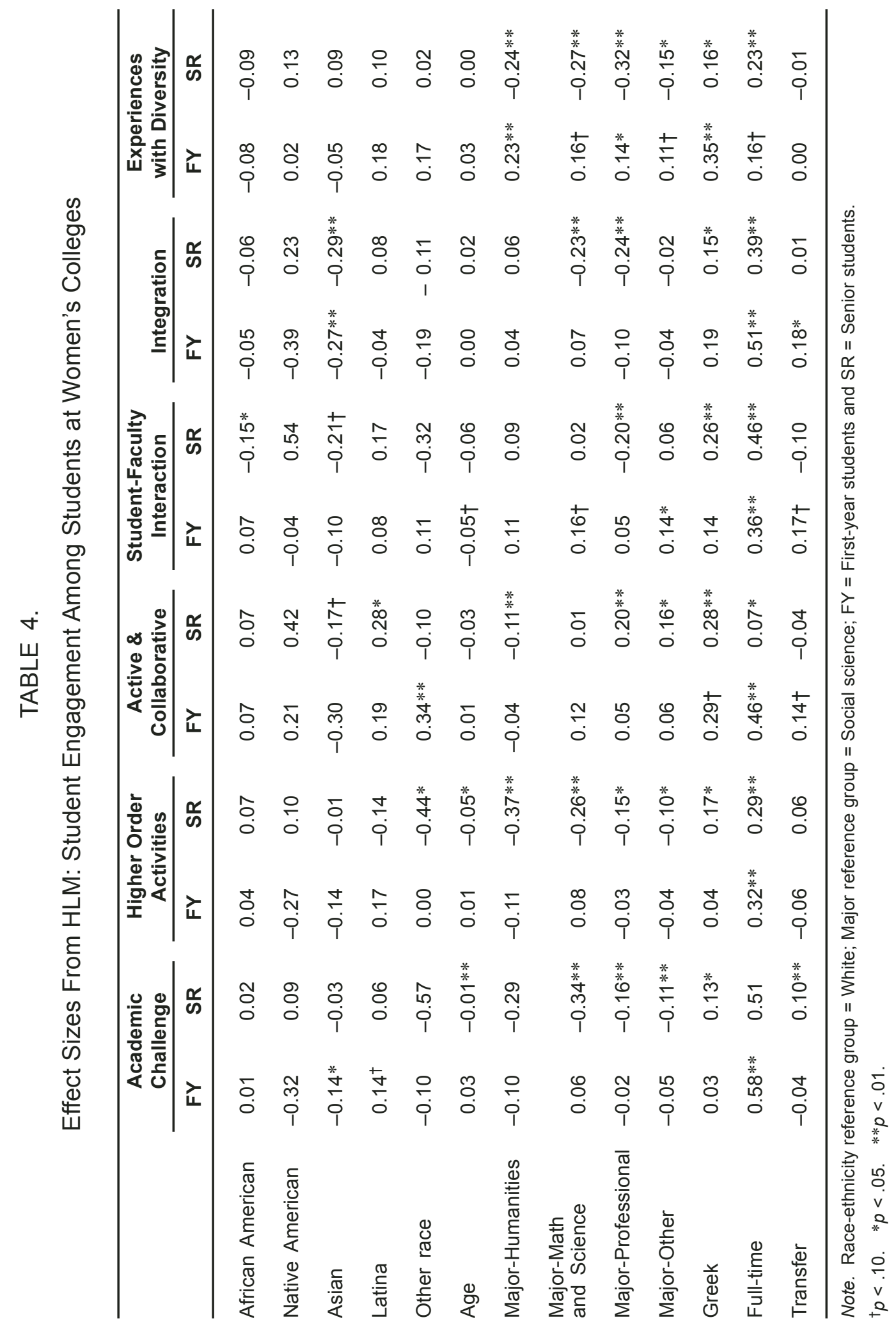


learning measure. However, these same students reported the lowest frequency of contacts with faculty members and experiences with diversity. Further, seniors in professional programs, math, and science scored the lowest on engagement in integration activities.

Contrary to national findings that show transfer students are generally less engaged overall (Kuh, 2003b), transfer students at women's colleges were as engaged as those who started at and were about to graduate from the same women's college. In some instances they were more engaged. For example, senior transfer students reported higher levels of academic challenge and first-year transfer students reported more integrative experiences.
Although some first-year students may have only spent a short time at another institution prior to transferring, these findings are noteworthy.

Supportive Campus Climate. Table 5 displays models predicting women's college students' perceptions of their campus climate and overall satisfaction. As with engagement, transfer students perceived levels of support comparable to other students on all four measures. Compared with White women, senior African American students reported significantly less support, and a moderate effect size resulted for the interpersonal support scale. Also, both first-year and senior African American students were less satisfied than

TABLE 5. Effect Sizes From HLM: Supportive Environment Among Students
at Women's Colleges

\begin{tabular}{|c|c|c|c|c|c|c|c|c|}
\hline & \multicolumn{2}{|c|}{$\begin{array}{c}\text { Supportive } \\
\text { Campus Climate }\end{array}$} & \multicolumn{2}{|c|}{$\begin{array}{l}\text { Interpersonal } \\
\text { Support }\end{array}$} & \multicolumn{2}{|c|}{$\begin{array}{l}\text { Support for } \\
\text { Success }\end{array}$} & \multicolumn{2}{|c|}{ Satisfaction } \\
\hline & FY & SR & FY & SR & FY & SR & FY & SR \\
\hline African American & -0.10 & $-0.15^{* *}$ & -0.02 & $-0.34 * *$ & 0.07 & 0.03 & $-0.30 * *$ & $-0.23 *$ \\
\hline Native American & 0.11 & 0.06 & -0.05 & 0.03 & 0.47 & 0.08 & -0.02 & 0.20 \\
\hline Asian & -0.01 & 0.04 & -0.06 & -0.08 & 0.02 & 0.12 & $-0.21 *$ & $-0.30 * *$ \\
\hline Latina & 0.09 & 0.11 & 0.22 & -0.03 & 0.06 & 0.19 & -0.15 & -0.01 \\
\hline Other race & 0.17 & -0.25 & 0.08 & -0.23 & 0.30 & -0.23 & 0.10 & -0.30 \\
\hline Age & $0.10 *$ & 0.02 & -0.03 & $0.13^{*}$ & -0.04 & -0.06 & $0.09 * *$ & $0.13 * *$ \\
\hline Major-Humanities & $0.24 * *$ & -0.07 & $0.17^{*}$ & -0.03 & -0.01 & -0.07 & $0.17 *$ & -0.02 \\
\hline $\begin{array}{l}\text { Major-Math and } \\
\text { Science }\end{array}$ & $0.14^{\dagger}$ & -0.07 & 0.13 & 0.06 & -0.09 & -0.15 & 0.05 & $-0.17^{*}$ \\
\hline Major-Professional & $0.17 *$ & $-0.21 * *$ & 0.10 & $-0.13^{\dagger}$ & -0.03 & $-0.23 * *$ & 0.11 & $-0.19 * *$ \\
\hline Major-Other & $0.11 *$ & -0.05 & 0.07 & 0.01 & -0.01 & -0.09 & 0.06 & -0.05 \\
\hline Greek & $0.24 *$ & $0.24 * *$ & $0.33 * *$ & $0.12^{\dagger}$ & 0.18 & $0.29 * *$ & $0.29 * *$ & $0.23 * *$ \\
\hline Full-time & 0.14 & $0.16 *$ & 0.14 & $0.13^{\dagger}$ & $0.22 *$ & $0.13^{\dagger}$ & 0.13 & $0.13^{\dagger}$ \\
\hline Transfer & -0.04 & -0.05 & 0.03 & -0.07 & 0.09 & -0.04 & 0.06 & -0.02 \\
\hline
\end{tabular}

Note. Race-ethnicity reference group $=$ White; Major reference group $=$ Social science $;$ FY $=$ First-year students and $\mathrm{SR}=$ Senior students.

${ }^{\dagger} p<.10 . \quad * p<.05 . \quad * * p<.01$. 
TABLE 6.

Effect Sizes From HLM: Self-Reported Gains Among Students
at Women's Colleges

\begin{tabular}{|c|c|c|c|c|c|c|c|c|}
\hline & \multicolumn{2}{|c|}{$\begin{array}{l}\text { General } \\
\text { Education }\end{array}$} & \multicolumn{2}{|c|}{$\begin{array}{l}\text { Understanding } \\
\text { Self and Others }\end{array}$} & \multicolumn{2}{|c|}{$\begin{array}{l}\text { Quantitative } \\
\text { Skills }\end{array}$} & \multicolumn{2}{|c|}{$\begin{array}{l}\text { Community } \\
\text { Welfare }\end{array}$} \\
\hline & FY & SR & FY & SR & FY & SR & FY & SR \\
\hline African American & $0.12 *$ & 0.10 & $0.11 *$ & -0.01 & $0.22 * *$ & 0.16 & 0.10 & $0.20 * *$ \\
\hline Native American & -0.53 & 0.00 & 0.03 & -0.14 & 0.07 & 0.19 & -0.43 & 0.43 \\
\hline Asian & -0.07 & -0.05 & 0.10 & $0.20 * *$ & 0.07 & $0.36 * *$ & -0.01 & $0.15 *$ \\
\hline Latina & 0.06 & 0.08 & $0.26^{\dagger}$ & 0.04 & 0.06 & 0.06 & $0.33^{*}$ & 0.08 \\
\hline Other race & 0.05 & -0.41 & -0.13 & -0.24 & 0.04 & 0.02 & -0.09 & $-0.63 *$ \\
\hline Age & 0.04 & 0.04 & 0.01 & -0.03 & $0.07^{\dagger}$ & -0.01 & 0.01 & -0.03 \\
\hline Major-Humanities & -0.11 & $-0.14 *$ & -0.07 & $-0.19 * *$ & -0.24 & $-0.53^{* *}$ & $-0.15^{*}$ & $-0.28 * *$ \\
\hline $\begin{array}{l}\text { Major-Math and } \\
\text { Science }\end{array}$ & -0.11 & $-0.44 * *$ & -0.10 & $-0.25^{* *}$ & $0.56 * *$ & $0.33^{* *}$ & -0.11 & $-0.32 * *$ \\
\hline Major-Professional & 0.01 & $-0.22 * *$ & -0.04 & $-0.22 * *$ & $0.14^{\dagger}$ & -0.07 & -0.01 & $-0.27 * *$ \\
\hline Major-Other & -0.05 & -0.08 & -0.02 & $-0.11 *$ & 0.03 & -0.06 & 0.01 & $-0.15^{*}$ \\
\hline Greek & 0.07 & 0.10 & $0.20 *$ & $0.26 *$ & $0.16^{\dagger}$ & 0.12 & $0.36 * *$ & $0.23 * *$ \\
\hline Full-time & $0.25^{\dagger}$ & $0.21 *$ & $0.19^{\dagger}$ & $0.20 *$ & $0.29 *$ & 0.14 & 0.16 & $0.21 * *$ \\
\hline Transfer & -0.11 & -0.06 & -0.04 & -0.11 & -0.06 & 0.08 & -0.11 & $-0.17 *$ \\
\hline
\end{tabular}

Note. Race-ethnicity reference group $=$ White. Major reference group $=$ Social science. $\mathrm{FY}=$ First-year students and $\mathrm{SR}=$ Senior students.

${ }^{\dagger} p<.10 . \quad * p<.05 . \quad * * p<.01$.

White students. In addition, APA students at women's colleges were less satisfied than their White counterparts.

As with the engagement measures, students' perceptions of the campus climate differed by major field. Seniors in professional majors had somewhat less positive views of the campus climate and reported the lowest levels of satisfaction. Conversely, students majoring in the social sciences reported the most positive perceptions of the campus climate and highest levels of satisfaction.

Self-Reported Gains. Table 6 shows the results from the models of self-reported gains. First-year African American students reported greater gains than White students in general education, understanding self and others, and quantitative skills. Senior African American students reported greater gains in their willingness to contribute to the welfare of their community and senior APA students indicated greater gains than White students in understanding self and others, quantitative skills, and desire to contribute to their community. Math and science majors had the lowest gains for three of the four measures; however, as expected, they reported the greatest gains of any group in the area of quantitative skills. Social science majors had the highest gains of all majors in general education knowledge, understanding self, and desire to do community service. In general, transfer students were 
comparable to seniors who started at the women's college, with one exception; senior transfer students gained less in their commitment to contribute to the welfare of their community.

\section{DISCUSSION}

The results from this study are consistent with other research studies, which show that women who attend a women's college are advantaged in terms of the nature and frequency with which they engage in educationally purposeful activities and in the progress they make in a variety of desirable outcomes of college. These advantages exist independent of institutional selectivity.

More specifically, women at women's colleges engage more frequently in effective educational practices at levels that exceed those of their counterparts at coeducational institutions. Indeed, on almost every engagement measure, women at single-sex colleges scored higher. They also reported making more progress toward a variety of desirable outcomes of college. Women's colleges also appear to be transfer-friendly, in that the pattern of advantages also held for this group of students who are typically less engaged at other types of institutions. True to their word, these colleges appear to create a climate where women are encouraged to realize their potential and become involved in various facets of campus life, inside and outside the classroom.

The high levels of academic challenge found at women's colleges appears to be a reflection of "taking women seriously," in that women are experiencing high expectations for student performance and are deeply engaged in intellectual and creative activities. First-year students and particularly seniors at women's colleges report significantly higher levels of academic challenge than women at coeducational institutions. This suggests that women's colleges may create climates in which students are encouraged to spend significant amounts of time studying and working hard to meet the expectations of instructors. Consonant with the work of Smith et al. (1995), women at women's colleges perceive the environment to require a high level of academic involvement. As a result, they expect to work hard to meet these high expectations. First-year students and seniors at women's colleges also experience more integrative learning experiences, which means they are connecting and synthesizing information with prior learning in ways that are more likely to become part of their approach to new phenomena and efforts to see things from different perspectives (Ramsden, 2003; Tagg, 2003). Seniors appear to benefit the most from the emphasis that women's colleges place on higher order cognitive activities in coursework. Although the level of academic work expected of students who attend the most selective women's colleges has long been touted as a defining characteristic, this study suggests that many women's colleges indeed provide women a challenging academic experience.

The advantages of women's colleges are said to be due in part to the availability of more female mentors and role models among the faculty and top administrators, greater opportunities for and participation in student leadership roles, and higher percentages of students enrolled in the traditionally male disciplines of math, science, and engineering (Women's College Coalition, n.d.; Langdon, 2001; Tidball et al., 1999). Our findings showing that students at women's colleges interact more frequently with faculty suggest that faculty members at women's colleges may be more accessible and that students have more opportunities to talk with faculty members outside of class than women at coeducational institutions. This finding lends further insight into the discussions raised by Tidball (1973, 
1980) and Kim and Alvarez (1995), regarding the advantages of the number of female faculty at women's colleges, by suggesting that it is the frequency of interactions among students and faculty members at women's colleges that makes a positive educational difference for women.

Indeed, one could reasonably assume that high levels of student-faculty interaction create opportunities for mentorship, such as providing advice and encouragement, recommendations for awards, internships or jobs, and involving students in research. These practices have been shown to have a positive influence on all students, and especially for women in science (Astin \& Sax, 1996). Women in science, mathematics, and engineering at coeducational institutions are often discouraged from pursuing science as a career because they have few interactions with role models that could support such a choice and further they perceive that science professors fail to take them seriously (Davis et al., 1996; Nelson \& Rogers, 2004; Seymour \& Hewitt, 1997). By establishing conditions that foster student-faculty interaction, women's colleges appear to provide important support for women in fields where they are underrepresented. This is true, for example, at Sweet Briar College where $60 \%$ of its graduates obtain advanced degrees, many of them in the sciences (Kuh, Kinzie, Schuh, Whitt \& Associates, 2005).

Results from this study also confirm that first-year students and seniors at women's colleges participate more actively in class, collaborate more frequently with their classmates in and out of class, and tutor other students more than women at coeducational institutions. Many have argued that because men are absent at women's colleges, women students at single-sex institutions have unique opportunities to engage in the education process (Conway, 1985; Langdon, 2001; Neff \& Harwood, 1991, Sharp, 1991; Women's
College Coalition, 1981). Unlike women at coeducational institutions, women at singlesex colleges assume all the leadership roles on campus, form study groups composed only of women, and take charge in laboratory exercises and classroom discussion. Our findings lend further support to Fassinger's (1995) conclusion that classroom conditions at coeducational institutions reduce women's levels of participation, whereas women's colleges seem to create classroom conditions in which women students are more likely to be actively engaged.

The results of this study also show that women's colleges seem to foster an environment that fuels women's understanding of self and others. That is, students at women's colleges report greater gains in self-understanding, including learning effectively on one's own and working effectively with others, than women at coeducational institutions. These skills, which are typically associated with career success and leadership, reveal some of the conditions that contribute to the high production of leaders from women's colleges (e.g., graduates of women's colleges constitute more than $20 \%$ of women in Congress and are $30 \%$ of a Business Week list of rising women stars in corporate America). Women's colleges also appear to create conditions that support women's development of quantitative skills, and these gains are particularly significant for science and math majors. This is contrasted with studies that show that women generally report relatively low gains in quantitative skills in college (see Davis et al., 1996).

Although it is not surprising that women's colleges would be more sensitive to issues of gender and sexism, this study also shows that both first-year students and seniors at women's colleges report significantly more experiences with diversity than women at coeducational institutions. This finding reinforces Smith et al.'s (1995) conclusion that women at women's colleges perceived that their insti- 
tutions cared about multiculturalism, and bolsters the importance of creating conditions that facilitate experience with diversity. This is one of the more important findings from this study, inasmuch as the topic of diversity has not been widely examined at women's colleges previously. Our findings indicate that compared to coeducational colleges, women's colleges both encourage and provide more opportunities for students to interact with people of different economic, racial, and social backgrounds.

\section{Limitations}

Although more than a third (26 of 68) of all women's colleges are included in this study, some highly selective women's colleges have not participated in NSSE and, therefore, are not represented in these findings. Because only one of the remaining five Seven Sisters schools is represented in the data, it is possible that the results would differ if more of these highly selective women's colleges were included. However, a recent study (Pascarella, Wolniak, \& Cruce, 2003) suggests little or no relationship between engagement in effective educational practices and selectivity. Additionally, we controlled for selectivity in all of our models.

Another limitation is related to the validity of self-reported gains. As Pascarella (2001) and others point out, gain scores may be confounded by students' entering characteristics. Though Pike (1999) provides some evidence to suggest that gain scores are not significantly related to entering ability, it is possible that women who select women's colleges and coeducational institutions may start at different levels of ability in certain areas, which affects the results in unknown ways. Although the concerns about self-reported data are legitimate, the gains measures are only one of several sets of dependent variables used in this study, and the concerns about the validity of self-reported gains should be interpreted in the context of the complete set of findings.

Also, some of the effect sizes are relatively small. For example, most of the effects of women's colleges (see Table 3) range from .10 to .20. At the same time, the pattern and magnitude of many of the effect sizes that favor women's colleges over coeducational institutions cannot be overlooked.

Further, assuming as many do that a Cronbach's alpha of .70 or above is acceptable (Nunnally, 1978), several of our alpha coefficients fall below this level. Most notable are the coefficients for active and collaborative learning ( $\alpha=.61$ for first-year students and $\alpha=.59$ for seniors). Although, these measures have a good deal of conceptual consistency to represent the major academic and social aspects of engagement activities, the marginal alphas on these two scales suggest that the results associated with these scales should be interpreted with some caution.

Finally, a self-selection bias may be reflected to an unknown degree in the results. We were unable to control for entering characteristics that may have affected our outcomes (Astin \& Lee, 2003). Perhaps the women who choose women's colleges are more predisposed than women who matriculate to other types of institutions to interacting with faculty members and engaging in collaborative learning. That is, women at women's colleges select women's colleges because they believe single-sex institutions provide an environment that offers more such opportunities. This possible self-selection may influence the relationship between women's colleges and the dependent measures of this study.

\section{Implications}

Given the advantages that women's colleges create for their students' learning and personal development, coeducational institutions seem to have something to learn. For example, 
coeducational institutions can invest more institutional attention to incorporating genderinclusive pedagogies in all courses, but particularly courses where women are underrepresented, and in creating conditions and programs that help women students develop greater self-understanding. In an effort to understand the circumstances in which students at women's colleges are enjoying such high levels of interaction with their faculty, the quality and frequency of student-faculty interaction at women's colleges might also be further examined. In addition, it would be instructive to document the initiatives that support such high levels of diversity experiences and discover the policies and practices that women's colleges enact to welcome and support transfer students and enable them to thrive socially and academically at levels comparable to students who begin college at the same school.

Clearly, women are the center of attention at women's colleges. Moreover, women's colleges typically provide programs, policies, and practices that, on average, engage their students at high levels in educationally purposeful activities. This strongly suggests that more women should give further consideration to attending such a college, especially because the advantages of a women's college education are not limited to only a small set of highly selective institutions, such as the Seven Sisters colleges. In one sense the exclusion of the Seven Sisters may make our findings even more noteworthy because other women's colleges generally are more accessible to and educate a larger proportion of women undergraduates.

To discover what it is that women's colleges do that seems to work so well, the programs, policies, and practices that effectively engage women at women's colleges warrant further examination. One key issue is to capture and describe in a fulsome way the curricular and out-of-class factors that seem to contribute to women developing skills in analyzing quantitative problems and self-understanding and to distill principles for designing experiences that can encourage more women in coeducational environments to acquire these competencies at higher levels. Research studies using a qualitative approach, including Manning (2000), Miller-Bernal (2000), and Whitt (1994), have demonstrated other salient cultural elements, and features of women's colleges. However, additional studies that document and discern pedagogical practices, educational policies, and programs that uniquely contribute to women's education at single-sex colleges should be explored. A cultural audit might discover aspects of the cultures of women's colleges that may inadvertently be contributing to the qualitatively different experiences of women on the same campus (Kuh et al., 1991).

Although women's colleges offer many advantages, they are not without shortcomings and challenges. Indeed, not all women attending women's colleges have similarly engaging experiences. For example, African Americans and APA students were less engaged and satisfied with their college experience than their White counterparts. Given that the enrollment of women of color at women's colleges continues to rise, with the largest increase being African American women (Guy-Sheftall, 1999), it behooves women's colleges to attend to the climate for learning on their campuses for students of color. It would be disappointing if women's collegeswith their tradition of providing access to those who historically have been denied educational opportunity-were unwittingly shortchanging women of color in the educational process. Historically Black women's colleges, which have a history of producing high proportions of successful graduates (Wolf-Wendel, 1998), should be examined as institutional models to 
improve the undergraduate experience for African American students at predominantly White women's colleges. Women of color, older women, lesbians, and women with disabilities may require specifically tailored institutional interventions to make the campus environment more welcoming. Other "outsiders" such as those for whom English is a second language and those from working class backgrounds may also require focused efforts.

\section{Conclusion}

As Geraldine Clifford (1993, p. 142) observed, "gender . . . is one of the most potent forces in shaping human institutions, including education." For more than 2 decades, proponents of women's colleges have asserted that such institutions offer female students a challenging, supportive, and developmentally powerful learning environment (Conway, 1985; Langdon, 2001; Neff \& Harwood, 1991, Sharp, 1991; Women's College Coalition, 1981). Our findings support this claim and plainly indicate that single-sex colleges are a vital postsecondary option for women. In many respects they are models of effective educational practice, institutions that have much to teach other types of colleges and universities that aspire to providing a challenging yet supportive educational environment for all their students.

Correspondence concerning this article should be addressed to Jillian Kinzie, Indiana University, Center for Postsecondary Research, 1900 E. 10th St. Suite 419, Bloomington, IN 47405; jikinzie@indiana.edu

\section{REFERENCES}

Astin, A. W. (1977). Four critical years. San Francisco: Jossey-Bass.

Astin, A. W. (1984). Student Involvement: A Developmental Theory for Higher Education. Journal of College Student Development, 25(4): 297-308.

Astin, A. W. (1993). What matters in college?: Four critical years revisited. San Francisco: Jossey-Bass.

Astin, A. W., \& Lee, J. J. (2003). How risky are one-shot crosssectional assessments of undergraduate students? Research in Higher Education, 44(6), 657-672.

Astin, H. S., \& Leland, C. (1991). Women of influence, women of vision: A cross-generational study of leaders and social change. San Francisco: Jossey-Bass.

Astin, H. S., \& Sax, L. J. (1996). Undergraduate women in science: Personal and environmental influences on the development of scientific talent. In C. Davis, A. Ginorio, C. Hollenshead, B. Lazarus, \& P. Rayman (Eds.), The equity equation: Women in science, mathematics, and engineering (pp. 96-121). San Francisco: Jossey-Bass.

Barron's Profiles of American Colleges, 2003. (2002). Hauppauge, N.Y: Baron's.

Bae, Y., Choy, S., Geddes, C., Sable, J., \& Snyder, T. (2000). Trends in educational equity of girls and women (NCES 2000030). Washington, DC: U.S. Government Printing Office.

Baxter Magolda, M. B. (1992). Knowing and reasoning in college: Gender-related patterns in students' intellectual development. San Francisco: Jossey-Bass.
Chickering, A. W., \& Gamson, Z. F. (1987). Seven Principles for Good Practice in Undergraduate Education. $A A H E$ Bulletin, March, 3-7.

Clifford, G. J. (1993). Shaking dangerous questions from the crease: Gender and American higher education. In J. S. Glazer, E. M. Bensimon, \& B. K. Townsend (Eds.), Women in higher education: A feminist perspective (pp. 135-174). Needham Heights, MA: Ginn Press.

Conway, J. K. (1985). Women's colleges: An educational force to be reckoned with. Change, 17, 30 .

Crosby, F., Allen, B., Culbertson, T., Wally, C., Morith, J., Hall, R., et al. (1994). "Taking selectivity into account: How much does gender composition matter?" National Women's Studies Association, 6(1), 107-18.

Davis, C., Ginorio, A. B., Hollenshead C. S., Lazarus, B. B., Rayman, P. M., \& Associates. (1996). The equity equation: Fostering the advancement of women in the sciences, mathematics, and engineering. San Francisco: Jossey-Bass.

Drew, T. L., \& Work, G. G. (1998). Gender-based differences in higher education: Gaining a broader perspective. Journal of Higher Education, 69(5), 542-555.

Fassinger, P. A. (1995). Understanding classroom interaction: Students' and professors' contributions to students' silence. Journal of Higher Education, 66(1), 82-96.

Giele, J. Z. (1987). Coeducation of women's education: A comparison of alumnae from two colleges. In C. Lasser (Ed.), Educating Men and Women Together (pp. 91-112). Urbana: University of Illinois Press. 
Guy-Sheftall, B. (1999). Diversity in women's colleges. In I. B. Harwarth (Ed.), A closer look at women's colleges. Washington, DC: National Institute on Postsecondary Education, Libraries, and Lifelong Learning. Office of Educational Research and Improvement. Retreived June 6, 2006, from http://www.ed.gov/pubs/WomensColleges/index.html

Hall, R. M., \& Sandler, B. R. (1982). The classroom climate: $A$ chilly climate for women? Washington, DC: Association of American Colleges.

Harwarth, I. B. (Ed.). (1999). A closer look at women's colleges. Washington, DC: National Institute on Postsecondary Education, Libraries, and Lifelong Learning. Office of Educational Research and Improvement. Retreived June 6, 2006, from http://www.ed.gov/pubs/WomensColleges/ index.html

Hayes, E., \& Flannery, D. D. (2000). Women as learners: The significance of gender in adult learning. San Francisco: Jossey-Bass.

Holland, D. C., \& Eisenhart, M. A. (1990). Educated in romance: Women, achievement, and college culture. Chicago: University of Chicago Press.

Hurtado, S., Carter, D. F., \& Kardia, D. (1998). The climate for diversity: Key issues for institutional self-study. In K. Bauer (Ed.), Campus climate: Understanding the critical components of today's colleges and universities (New Directions for Institutional Research No. 98, pp. 53-63). San Francisco: Jossey-Bass.

Kezar, A., \& Moriarty, D. (2000). Expanding our understanding of student leadership development: A study exploring gender and ethnic identity. Journal of College Student Development, 41, 55-69.

Kim, M. M. (2002). Cultivating intellectual development: Comparing women-only colleges and coeducational colleges for educational effectiveness. Research in Higher Education, 43(4), 447-481.

Kim, M., \& Alvarez, R. (1995). Women-only colleges: Some unanticipated consequences. Journal of Higher Education, 66(6), 641-668.

Kuh, G. D. (2001). Assessing what really matters to student learning: Inside the National Survey of Student Engagement. Change, 33(3), 10-17, 66.

Kuh, G. D. (2003a). The National Survey of Student Engagement: Conceptual framework and overview of psychometric properties. Retrieved July 10, 2005, from Indiana University Center for Postsecondary Research Web site: http://nsse.iub.edu/pdf/ conceptual_framework_2003.pdf

Kuh, G. D. (2003b). What we're learning about student engagement from NSSE. Change, 35(2), 24-32.

Kuh, G. D. (2005). Student engagement in the first year of college. In M. L. Upcraft, J. N. Gardner, \& B. O. Barefoot (Eds.), Challenging and supporting the first-year student: $A$ handbook for improving the first year of college (pp. 86-107). San Francisco: Jossey-Bass.

Kuh, G. D., Douglas, K. B., Lund, J. P., \& Ramin-Gyurnek, J. (1994). Student Learning Outside the Classroom: Transcending Artificial Boundaries. ASHE-ERIC Higher Education Report No. 8. Washington, DC: The George Washington University, Graduate School of Education and Human Development.
Kuh, G. D., Kinzie, J., Schuh, J. H., Whitt, E. J. \& Associates (2005). Student Success in College: Creating Conditions That Matter. San Francisco: Jossey-Bass.

Kuh, G. D., Schuh, J. H., Whitt, E. J., \& Associates. (1991). Involving colleges: Successful approaches to fostering student learning and development outside the classroom. San Francisco: Jossey-Bass.

Langdon, E. A. (2001). Women's colleges then and now: Access then, equity now. Peabody Journal of Education, 76(1), $5-30$.

Lee, V. E. \& Byrk, A. (1989). A multi-level model of the social distribution of educational achievement. Sociology of Education, 62, 172-192.

Lee, V. E., \& Smith, J. B. (1997). High school size. Which works best for whom? Educational Evaluation and Policy Analysis, 19, 205-227.

Manning, K. (1994). Metaphorical analysis in a constructivist study of college rituals. Review of Higher Education, 18(1), 45-60.

Manning, K. (2000). Rituals, ceremonies, and cultural meaning in higher education. Westport, CT: Bergin \& Garvey.

Mayer, D. P. (1998). Do new teaching standards undermine performance on old tests? Educational Evaluation and Policy Analysis, 20, 53-73

Miller-Bernal, L. (2000). Separate by degree: Women students' experiences in single-sex and coeducational colleges. New York: Peter Lang.

National Center for Education Statistics. (2006). Digest of Education Statistics 2005 (NCES. 2006-030). Washington, DC: U.S. Department of Education, National Center for Education Statistics. Washington, DC: U.S. Government Printing Office.

National Survey of Student Engagement. (2003). Converting data into action: Expanding the boundaries of institutional improvement. Bloomington: Indiana University Center for Postsecondary Research.

National Survey of Student Engagement. (2004). Student engagement: Pathways to collegiate success. Bloomington: Indiana University Center for Postsecondary Research.

Neff, L. A., \& Harwood, P. C. (1991). Creating empowering campus climates for women. Initiatives, 53(5), 31-39.

Nelson, D. J., \& Rogers, D. C. (2004). A national analysis of diversity in science and engineering faculties at research universities. Retrieved July 10, 2005, from the National Organization for Women Web site: http://www.now.org/ issues/diverse/diversity_report.pdf

Nidiffer, J. (2001). Crumbs from the boys' table. In J. Nidiffer \& C. T. Bashaw (Eds.), Women administrators in higher education (pp. 13-34). Albany: State University of New York Press.

Nidiffer, J., \& Bashaw, C.T. (2001) Women administrators in higher education. Albany: State University of New York Press.

Nunnally, J. (1978). Psychometric theory. New York: McGraw-Hill.

Pascarella, E. T. (2001). Using student self-reported gains to estimate college impact: A cautionary tale. Journal of College Student Development, 42, 488-492. 
Pascarella, E. T., \& Terenzini, P. T. (1991). How college affects students: Findings and insights from 20 years of research. San Francisco: Jossey-Bass.

Pascarella, E. T., \& Terenzini, P. T. (2005). How college affects students: Vol. 2. A 3rd decade of research. San Francisco: Jossey-Bass.

Pascarella, E. T., Whitt, E. J., Edison, M. I., Nora, A., Hagedorn, L. S., Yeager, P. M., et al. (1997). Women's perceptions of a "chilly climate" and their cognitive outcomes during the first year of college. Journal of College Student Development, 38, 109-124.

Pascarella, E. T., Wolniak, G., \& Cruce, T. (2003, November). College selectivity and good practices in undergraduate education. Paper presented at the annual meeting of the Association for the Study of Higher Education, Portland, OR.

Pike, G. R. (1999). The constant error of the halo in educational outcomes research. Research in Higher Education, 4O(1), 61-86.

Knapp, L.G., Kelly, J.E., Whitmore, R.W., Wu, S., Gallego, L.M., \& Grau, E. (2001). Postsecondary Institutions in the United States: Fall 2000 and Degrees and Other Awards Conferred: 1999-2000. Washington, DC: U.S. Department of Education, National Center for Education Statistics. Retrieved July 10, 2005 from http://nces.ed.gov/pubs2002/ 2002156.pdf

Ramsden, P. (2003). Learning to teach in higher education. London: Routledge Falmer.

Raudenbush, S. W., \& Bryk, A. S. (2002). Hierarchical linear models: Applications and data analysis methods. Thousand Oaks, CA: Sage.

Rice, J. K. (1991). Separation and the education of women. Initiatives, 53(5), 5-15.

Riordan, C. (1992). Single- and mixed-gender colleges for women: Educational, attitudinal, and occupational outcomes. Review of Higher Education, 15, 327-346.

Riordan, C. (1994). The value of attending a women's college: education, occupation, and income benefits. Journal of Higher Education, 65(4), 486-510.

Rosenthal, R., \& Rosnow, R. L. (1991). Essentials of behavioral research: Methods and data analysis (2nd ed.). New York: McGraw-Hill.

Sandler, B. R. (n.d.). The chilly climate: Subtle ways in which women are often treated differently at work and in classrooms. Retreived June 6, 2006, from http://www.bernicesandler. com/id23.htm

Sandler, B. R., Silverberg, L. A., \& Hall, R. M. (1996). The chilly climate: A guide to improve the education of women. Washington, DC: National Association for Women in Education.

Sebrechts, J. S. (1992). Cultivating scientists at women's colleges. Initiatives, 55(2), 45-51.

Seymour, E., \& Hewitt, N. M. (1997). Talking about leaving: Why undergraduates leave the sciences. Boulder, CO: Westview Press.

Sharp, M. K. (1991, Winter). Bridging the gap: Women's colleges and the women's movement. Initiatives, 53, 3-7.

Sharpe, N. K., \& Fuller, C. H. (1995). Baccalaureate origins of women physical science doctorates: Relationship to institutional gender and science discipline. Journal of Women and Minorities in Science and Engineering, 2(1), 1-15.
Smith, D. G. (1989). The challenge of diversity: Involvement or alienation in the academy? ASHE-ERIC Report No. 5. Washington DC: George Washington University, School of Education and Human Development.

Smith, D. G. (1990). Women's colleges and coed colleges: Is there a difference for women? Journal of Higher Education, 61(2), 181-195.

Smith, D. G., Morrison, D. E., \& Wolf, L. E. (1994). College as a gendered experience: An empirical analysis using multiple lenses. Journal of Higher Education, 65(6), 696-725.

Smith, D. G., Wolf, L. E., \& Morrison, D. E. (1995). Paths to success: Factors related to the impact of women's colleges. Journal of Higher Education, 66(3), 245-266.

Solomon, B. M. (1985). In the company of educated women: A history of women and higher education in America. New Haven, CT: Yale University Press.

Stoecker, J. L., \& Pascarella, E. T. (1991). Women's colleges and women's career attainments revisited. Journal of Higher Education 62(4), 394-406.

Tagg, J. (2003). The learning paradigm college. Boston: Anker.

Tidball, M. E. (1973). Perspectives on academic women and affirmative action. Educational Record, 54, 130-135.

Tidball, M. E. (1980). Women's colleges and achievers revisited. Signs: Journal of Women in Culture and Society, 5, 504-517.

Tidball, M. E. (1985). Baccalaureate origins of entrants into american medical schools. Journal of Higher Education 56, 385-402.

Tidball, M. E. (1986). Baccalaureate origins of recent natural science doctorates. Journal of Higher Education 57, 606-20.

Tidball, M. E., Smith, D. G., Tidball, C. S., \& Wolf-Wendel, L. E. (Eds.). (1999). Taking women seriously: Lessons and legacies for educating the majority. Phoenix, AZ: Oryx Press.

Tinto, V. (1987). Leaving College: Rethinking the Causes and Cures of Student Attrition. Chicago: University of Chicago Press.

U.S. Department of Labor. (2003). Highlights of women's earnings in 2002. Bureau of Labor Statistics, Report 972. Retrieved July 10, 2005 from http://www.bls.gov/cps/ cpswom2002.pdf

Whitt, E. J. (1994). “I can be anything!” Student leadership in three women's colleges. Journal of College Student Development, 35, 198-207.

Whitt, E. J., Edison, M. I., Pascarella, E. T., Nora, A., \& Terenzini, P. T. (1999). Women's perceptions of a "chilly climate" and cognitive outcomes in college: Additional evidence. Journal of College Student Development, 40, 163-177.

Wolf-Wendel, L. E. (1998). Models of successful AfricanAmerican, European American and Hispanic women. Journal of Higher Education, 69(2), 144-172.

Wolf-Wendel, L. E., Baker, B., \& Morphew, C. (2000). Dollars and \$ense: Institutional resources and the baccalaureate origins of women doctorates. Journal of Higher Education 71(2), 165-189.

Women's College Coalition. (n.d.). Retrieved November 2, 2003, from http://www.womenscolleges.org

Women's College Coalition. (1981). A study of the learning environment at women's colleges. Washington, DC: Author. 